\title{
Current usefulness of Credé's method of preventing neonatal ophthalmia
}

\author{
LUSA REIS SILVA^, RICARDO QUEIROZ GURGEL ${ }^{\star}$, DOROTHY RIBEIRO \\ RESENDE LIMA* \& LUIS E. CUEVAS $^{\dagger}$
}

\begin{abstract}
${ }^{\star}$ Federal University of Sergipe, Aracaju, Brazil and ${ }^{\dagger}$ The Liverpool School of Tropical Medicine, Liverpool, $U K$
\end{abstract}

(Accepted November 2007)

\begin{abstract}
The conjunctiva's bacterial profile at birth and 1 week after Credé's gonoccocal ophthalmic prophylaxis was evaluated over a 3-month period using culture and direct immunofluorescence. Thirty-four neonates received $10 \%$ silver vitellinate and 42 sterile saline. Chlamydia trachomatis was recovered in $7 / 34$ and $9 / 42$ neonates receiving silver vitellinate and saline at birth and in $8 / 34$ and 12/42 after 1 week, respectively. Neisseria gonorrhoeae was not identified. Credé's may not be the ideal prophylactic method in areas with a low prevalence of $N$. gonorrhoeae.
\end{abstract}

\section{Introduction}

Since its introduction in 1881, Credé's method of reducing neonatal ophthalmia has been used worldwide. ${ }^{1}$ It requires the instillation of one drop of $1 \%$ silver nitrate (AgNO3) at birth but is often followed by chemical conjunctivitis. Although alternative solutions such as silver vitellinate, tetracycline or erythromycin ${ }^{2,3}$ are reported to be less effective, the low incidence of gonoccocal ophthalmia in many settings encourages services to change their protocols. ${ }^{4,5}$ There are no recent studies describing the side-effects of silver vitellinate. In populations with a low incidence of gonoccocal ophthalmia, the changes in the ocular flora associated with its use might be different from those reported in highincidence populations. This study describes the bacterial conjunctival profile of neonates

Reprint requests to: Dr Ricardo Q. Gurgel, The Liverpool School of Tropical Medicine, Pembroke Place, Liverpool L3 5QA, UK. Email: ricardoqg@ infonet.com.br; fax: +441517053329. receiving silver vitellinate at birth and 1 week after birth and compares these changes with a group of neonates receiving ocular toilette with sterile saline.

\section{Methods}

This descriptive study of neonates was conducted in a maternity hospital in Aracaju, Brazil. The incidence of gonoccocal ophthalmia in this setting is very low $(<1 \%)$, while the incidence of Chlamydia trachomatis is unknown. The hospital guidelines advise the use of $1 \%$ silver nitrate for all newborns. Owing to procurement problems, however, the hospital was not employing prophylaxis at the time of the study. After obtaining maternal informed consent, neonates were randomised to receive either one drop of $10 \%$ silver vitellinate (Argyrol ${ }^{\circledR}$ Laboratories, Allergan Frumtost) or saline solution in both eyes soon after birth and when the child was stable.

Two conjunctival specimens were collected within the 1 st 2 hours of life and 
before any cleaning or eye instillations. Specimens were collected by rolling cotton swabs on the inferior corner of the conjunctiva using a standardised technique. ${ }^{6}$ They were cultured on several media for aerobic and anaerobic bacteria including enriched chocolate agar ${ }^{6}$ and examined for C. trachomatis using a direct immunofluorescence (DIF) test. ${ }^{7}$ Participants were then followed 1 week later at their home or health centre when two further swabs were collected.

\section{Analysis}

The proportions of cultures and DIF tests that were positive on enrolment and followup were compared by treatment group using the $\chi^{2}$ test with Yates' correction or Fischer's Exact test, where appropriate. The study protocol was approved by the Research Ethics Committee of the Federal University of Sergipe, Brazil.

\section{Results}

A total of 76 newborns were enrolled from March to May 2006 (Table 1). Of these, 34 received silver vitellinate and 42 received saline. Twenty-nine infants using silver vitellinate and 17 using saline were followed 1 week later. Ten $(29 \%)$ and three $(7 \%)$ children receiving silver vitellinate and saline, respectively, had positive cultures on enrolment $(p=0.02)$. Similarly, seven $(20 \%)$ and nine $(21 \%)$ of the children receiving silver vitellinate and saline, respectively, had a positive DIF for C. trachomatis on enrolment. Positive cultures were recovered more frequently during follow-up, and had increased from $13(38 \%)$ to $35(93 \%) 1$ week later $(p<0.001)$. C. trachomatis was still the most frequently detected microorganism 1 week later $(23 \%$ in the silver vitellinate and $31 \%$ in the saline groups). Many infants had discordant DIF results on follow-up, with nine of 42 specimens testing negative at birth and positive 1 week later (Table 1). The proportions of infants with positive cultures and DIF results did not differ by treatment group.

The profile for the two collections included Staphylococus aureus $(5 \%$ and $21 \%)$, Staphylococcus epidermidis (0\% and $17 \%)$, micrococcus spp (5\% and $0 \%)$

TABLE 1. Bacterial culture and Chlamydia trachomatis direct immunofluorescence (DIF) results at birth and after 1 week follow-up by treatment group.

\begin{tabular}{|c|c|c|c|c|c|c|c|c|}
\hline & \multicolumn{5}{|c|}{ Vitellinate group } & \multicolumn{3}{|c|}{ Saline group } \\
\hline & \multicolumn{8}{|c|}{ Culture on follow-up } \\
\hline & Positive & Negative & Missing & Total & Positive & Negative & Missing & Total \\
\hline \multicolumn{9}{|c|}{ Culture at birth } \\
\hline Positive & 7 & 3 & - & 10 & 1 & 1 & 1 & 3 \\
\hline Negative & 16 & 4 & 2 & 22 & 11 & 4 & - & 15 \\
\hline Missing & 2 & - & - & 2 & 3 & - & 21 & 24 \\
\hline \multirow[t]{3}{*}{ Total } & 25 & 7 & 2 & 34 & 15 & 5 & 22 & 42 \\
\hline & \multicolumn{8}{|c|}{ DIF on follow-up } \\
\hline & Positive & Negative & Missing & Total & Positive & Negative & Missing & Total \\
\hline $\begin{array}{l}\text { Pos at birth } \\
\text { Positive }\end{array}$ & 4 & 1 & 2 & 7 & 7 & 8 & 1 & 9 \\
\hline Negative & 4 & $17^{\star}$ & 6 & 27 & 5 & 16 & - & 21 \\
\hline Missing & - & - & - & - & - & 2 & 3 & 5 \\
\hline Total & 8 & 18 & 8 & 34 & 12 & 26 & 1 & 42 \\
\hline
\end{tabular}

$\star$ Fisher Exact test, $p=0.02$. 
and gram-negative bacteriae ( $5 \%$ and $5 \%$ ). $N$. gonorrhoeae was not found. Negative samples decreased from $62 \%$ to $19 \%$ (Table 2).

\section{Discussion}

C. trachomatis is the bacterium most frequently found in children with clinical signs of neonatal ophthalmia, even in areas such as sub-Saharan Africa where N. gonorrhoeae is still prevalent. ${ }^{8}$ This bacterium, while still common in some regions, is rare in Latin America $(<1 \% \text { in most places })^{2}$ and, because silver nitrate produces chemical conjunctivitis and is ineffective against $C$. trachomatis, alternative solutions for preventing neonatal ophthalmia are increasingly being used. ${ }^{8}$

During the 3 months of data collection, no cases of $N$. gonorrhoea were detected. Bacterial colonisation increased and in both groups its profile changed after 1 week. Staphylococcus aureus and Staph. epidermidis had increased colonisation after 1 week and C. trachomatis was the most frequently detected bacterium in both groups at birth and during follow-up. Silver nitrate and silver vitellinate are both ineffective against C. trachomatis, although the latter produces less chemical conjunctivitis. Whether the Credé method is still suitable in locations with very low $N$. gonorrhoeae prevalence is now in question, although alternative

TABLE 2. Micro-organism profile at birth and after 1 week of follow-up.

Micro-organisms

Birth, $n(\%)$ Follow-up, $n(\%)$

$\begin{array}{lcc}\text { Chlamydia trachomatis } & 10(18) & 14(22) \\ \text { Staphylococus aureus } & 3(5) & 13(21) \\ \text { Staphylococus epidermidis } & - & 11(17) \\ \text { Staphylococcus spp } & 3(5) & 10(16) \\ \text { Micrococcus spp } & 3(5) & - \\ \text { Other gram-negative } & 3(5) & 3(5) \\ \text { No growth } & 34(64) & 12(19) \\ \text { Total } & 56(100) & 63(100)\end{array}$

* Some samples had more than one micro-organism. solutions are not effective against the most common aetiological agents. ${ }^{8}$ Furthermore, some of these solutions include antibiotics which might induce bacterial resistance or patient sensitisation.

Regular antenatal care, starting during early pregnancy, and screening for sexually transmitted diseases (STD) reduce the number and severity of cases of neonatal ophthalmia. $^{2}$ The World Health Organization proposes a syndromic approach for screening for STDs and for treating suggestive case empirically, thus reducing the risk of infection during and after delivery. ${ }^{9}$

Brazil is a large country with many disparities in healthcare provision and socio-economic conditions, but women there have relatively good access to antenatal care. In Aracaju, it is reported that $89 \%$ of mothers attend antenatal care in public healthcare facilities and that good preventive practices including HIV/STD testing at birth are being implemented. ${ }^{10}$

The Credé method did not affect the results of culture and DIF. As it frequently leads to chemical conjunctivitis, it may be unnecessary in places such as Aracaju where there is a low prevalence of $N$. gonorrhoeae and cases can be treated as they are diagnosed. This might not be the case elsewhere (such as some areas of subSaharan Africa and Asia) where the prevalence of $N$. gonorrhoeae is high and preventive strategies are required for $C$. trachomatis and N. gonorrhoeae.

\section{References}

1 Credé CSF. Die Verhütung der Augenentzündung der Neugeborenem. Archiv Gynaekologie 1881; 17:50-3.

2 Foster A, Klauss V. Ophthalmia neonatorum in developing countries. N Engl F Med 1995; 332:600-1.

3 Palazzi MA, Muño EH, Massaini MG, Aurichio MT, Barros OM. Estudo da aplicabilidade do método de Credé em maternidades do município de São Paulo. Rev Bras Oftalmol 1991; 50:39-44.

4 Isenberg SJ, Apt L, Signore M, Gichuhi S, Berman NG. A double application approach to ophthalmia neonatorum prophylaxis. Br f Ophthalmol 2003; 87:1449-52. 
5 O'Hara MA. Oftalmia neonatal. In: Nelson LB, ed. Oftalmologia Pediátrica-Clínicas Pediátricas da América. Rio de Janeiro: Editora Interlivros, 1999; 783-91.

6 Oplustil CP, Zoccoli CM, Tabouti NR. Procedimentos Básicos em Microbiologia Clínica. São Paulo: Sarvier, 2004.

7 Valencia C, Prado V, Rios M, Cruz MA, Pilorget JJ. Prevalencia de Chlamydia trachomatis en conjunctivitis neonatal determinada mediante las técnicas de inmuno-fluorescencia y amplificación génica. Rev Méd Chile 2000; 128:758-65.
8 Schaller VC, Klauss V. Is Crede's prophylaxis for ophthalmia neonatorum still valid? Bull WHO 2001; 79:262-3.

9 Moherdaui F, Vuylsteke B, Siqueira LFG, et al. Validation of national algorithms for the diagnosis of sexually transmitted diseases in Brazil: results from a multicenter study. Sex Transm Inf 1998; 74:S38-43.

10 Lemos LMD, Gurgel RQ, Dal Fabbro AL. Prevalência da infecção por HIV em parturientes de maternidades vinculadas ao SUS. Rev Bras Ginecol Obstet 2005; 27:32-6. 